Editorial

\title{
Societal Relations to Nature in Times of Crisis-Social Ecology's Contributions to Interdisciplinary Sustainability Studies
}

\author{
Johanna Kramm ${ }^{1}{ }^{*}$, Melanie Pichler ${ }^{2}$, Anke Schaffartzik ${ }^{2}$ and Martin Zimmermann ${ }^{1}$ \\ 1 ISOE-Institute for Social-Ecological Research, 60486 Frankfurt am Main, Germany; zimmermann@isoe.de \\ 2 Institute of Social Ecology, Alpen-Adria University Klagenfurt-Wien-Graz, A-1070 Vienna, Austria; \\ melanie.pichler@aau.at (M.P.); anke.schaffartzik@aau.at (A.S.) \\ * Correspondance: kramm@isoe.de; Tel.: +49-697076919-16
}

Received: 8 February 2017; Accepted: 15 February 2017; Published: 26 June 2017

\begin{abstract}
During the second half of the 20th century, the crisis of societal relations to nature emerged as the subject of an international scientific, political, and popular debate. Anthropogenic climate change, loss of biodiversity, resource peaks, or local air and water pollution are symptoms of this crisis. Social ecology provides an inter- and transdisciplinary take on sustainability research and is well-equipped to respond to the research challenges associated with this crisis. Social ecology comprises different schools of thought, of which two initiated this special issue on "State of the Art and Future Prospects" for the research field. The approaches to social ecology of the ISOE-Institute for Social-Ecological Research in Frankfurt, Germany, and the Institute of Social Ecology (SEC) in Vienna, Austria are based on a common understanding of the challenges posed by social-ecological crises. In how these social ecologies tackle their research questions, conceptual differences become evident. In this article, we provide an overview of social ecology research as it is conducted in Frankfurt and in Vienna. We discuss how this research responds to the ongoing crisis and conclude by identifying important future prospects for social ecology.
\end{abstract}

Keywords: social ecology; societal relations to nature; colonization; metabolism; regulation; transformation; social-ecological crisis

\section{Introduction}

During the second half of the 20th century, a deepening crisis of the societal relations to nature emerged as the subject of an international scientific, political, and popular debate [1]. In the early 1970s, the Club of Rome commissioned "The Limits to Growth" study [2]. During that same decade, large-scale social and environmental disasters occurred, for example, at the nuclear reactors in Harrisburg and Chernobyl and the chemical plants in Bhopal and Seveso. In the 1980s, the Brundtland Report [3] popularized the term "sustainable development" and initiated an increasingly mainstream discourse on the interaction between socio-economic development and environmental change. The UN Sustainable Development Goals (SDGs) are the most recent and currently highly visible attempt to address the social, economic, and environmental pillars of sustainability.

The development of policy interest in sustainability was accompanied by an intensifying social-ecological crisis: anthropogenic climate change, widespread and extremely rapid loss of biodiversity, resource peaks and fluctuating supply, and local air and water pollution are symptoms of this crisis. In all these symptoms, humans are both 'perpetrators' and 'victims'. It is human activity that has caused far-reaching and hazardous change to the environment, so much so that a new geological epoch - the Anthropocene-has been defined [4]. The challenge for sustainability research is immense. To identify the underlying drivers of detrimental (global) environmental change is a 
prerequisite for any contribution to much-needed transformations of societal relations to nature [5]. Such research is conducted in the face of controversy, as the role of human activity in causing epochal environmental change has repeatedly been disputed; the contestation of anthropogenic climate change by certain societal groups is among the most well-known examples. Research on the crisis of the societal relations to nature must therefore not only address questions of societal organization and drivers of environmental change, it must also be able to consider research and academia, disciplines and schools of thought as its object to contribute to transformative knowledge creation.

Social ecology provides an inter- and transdisciplinary take on sustainability research and is well-equipped to respond to these challenges. Social ecology is, however, not a conceptual monolith but comprises different schools of thought [6]. This special issue predominantly brings together contributions from two such schools: the ISOE-Institute for Social-Ecological Research in Frankfurt, Germany, and the Institute of Social Ecology (SEC) in Vienna, Austria. In this editorial, we introduce the institutes' past and recent advances in social ecology, focusing in particular on their respective conceptual research programs, approaches, and methodologies. Based on this review, we identify how social ecology addresses the crisis of the societal relations to nature and discuss some of the research frontiers that have recently emerged. We conclude by reflecting on important future perspectives for social ecology.

\section{Frankfurt Social Ecology}

Frankfurt Social Ecology defines itself as a critical, transdisciplinary science of societal relations to nature (SRN) (for a detailed account on Frankfurt Social Ecology, see Hummel et al., this issue). The concept of SRN emerged almost 30 years ago within the political context of the 1980s and 1990s. This period was marked by the debates of the environmental movement, the women's movement and other social movements. Corresponding debates centered on various versions of Marxist, feminist and ecological critiques of ecological destruction, dehumanizing modes of production, patriarchal rule, of the naive belief in progress, and of an objectivist concept of knowledge. Furthermore, challenging theoretical questions raised by the "new social movements" were discussed. Referring to Critical Theory, the ecological crisis was understood in several dimensions as a crisis of politics, gender relations, and science. Moreover, it became clear that disciplinary research was often not able to tackle social-ecological problems. Frankfurt Social Ecology therefore pursues a mode of transdisciplinary research that aims to bring together knowledge from the natural and social sciences with non-scientific knowledge.

The SRN concept refers to patterns that emerge from culturally specific and historically variable forms and practices in which individuals, groups, and cultures design and regulate their relations to nature. SRN are formed either directly through the interaction of individual actors or are mediated by institutions and functional systems. The spectrum of forms and practices ranges from the appropriation of natural resources to the aesthetic contemplation of nature, from physical measurement to environmental education. In the SRN concept, physical-material and cultural-symbolic attributes of the patterns are differentiated. This distinction emphasizes the materiality of all natural relations under consideration and, at the same time, takes the relations' embeddedness in symbolic orders, interpretive contexts and social constructions into account. Material aspects do not simply exist as part of a reality independent of interpretation. Rather, they are the result of social and cognitive processes of construction. This is of particular relevance since the material regulation of modern societies' relations to nature is increasingly dependent on scientific models and technical principles. Similar distinctions are also made in other research approaches, for instance, in Vienna Social Ecology [7], in the theory of reflexive modernization [8], or in actor-network theory [9,10].

At its most fundamental level, the SRN concept evolves around the idea of basic needs. SRN should be regulated in a way guaranteeing that all human beings can satisfy their basic needs. This dimension is closely related to the ideas of justice, equity, and sustainable development. Such "basal societal relations to nature" are essential for individual and societal reproduction, as well 
as for the capacity of individuals and societies to thrive. Basal SRN are, for instance, work and production, land use and nutrition, sexuality and reproduction, hygiene and health care, or movement and mobility. If the regulation of basal SRN fails, spatially, temporally, and socially extensive crises or societal collapse might occur. In the case of global water or food crises, for instance, large parts of the world population cannot satisfy their vital needs.

In Frankfurt Social Ecology, the idea of the regulation of SRN is incorporated in the concept of provisioning systems: as a reinterpretation of the social-ecological systems approach, this concept allows for the empirical analysis of SRN (Hummel et al., this issue).

The notions of regulation and transformation play an important role in the context of the crisis of societal relations to nature. In this context, regulation has a normative dimension since there has to be a vision of successful regulation. Different disciplinary approaches to regulation can be pursued, for instance, through a technological cybernetic understanding or political-economic theories of regulation. Frankfurt Social Ecology distinguishes patterns and modes of regulation: "Whereas patterns of regulation stand for the material and symbolic aspects of the organization of the individual and social satisfaction of needs, modes of regulation represent a second order regulation, which mirrors the norms and power structures of a society" (Hummel et al., this issue). Changes in the modes and patterns of regulation are conceptualized as social-ecological transformations (see Görg et al., this issue).

The focus on real-world problems (in contrast to purely scientific problems) and the development of possible solutions are constitutive for Frankfurt Social Ecology. In transdisciplinary research, real-world problems are the starting point of the research, and contributing to their solution is the research objective [11,12]. Research is conducted to gain a better understanding of social-ecological problems and to study alternative options for action that can show the way out of problematic states or processes. Transdisciplinarity is a mode of research in which the main assumption is that societal and scientific problems are interlinked. The model of an ideal transdisciplinary research process comprises three phases [13]: In the first phase of problem transformation, societal and scientific problems are set in relation to each other to form a common research object. In the second phase of interdisciplinary integration, new knowledge is produced by the integration of scientific and non-scientific knowledge. In the third phase of transdisciplinary integration, the results of the second phase are assessed in terms of their contribution to societal and scientific progress.

Frankfurt Social Ecology's research results provide options for sustainable solutions, such as integrated management strategies for water and land resources (see Liehr et al. in this issue), or innovative concepts for adapting aged water infrastructures to changing conditions and strategies, in order to minimize critical substances, such as pharmaceuticals, in ground- and drinking water [14]. Designs for transport and mobility, or urban developments, can result from research projects by integrating lifestyle concepts and the quality of life in urban areas [15]. Studies of changes in consumption patterns, lifestyles, and everyday practices are conducted to identify recommendations for reducing carbon emission in households [16,17]. In the field of biodiversity, the interactions between biodiversity, ecosystem services and population dynamics are in the focus of current research $[18,19]$. Finally, scientific and practice-related foundations for transdisciplinary research are developed, and the impacts of its application on research and cognitive processes are examined [20,21]. Concepts such as ecosystem services (see Mehring et al. and Schleyer et al. in this issue), (social-ecological) risks (see Völker et al. in this issue, [22]), vulnerability [21], resilience or lifestyles [23] are fruitfully integrated. These different approaches stem from the humanities, social, natural and engineering sciences. Their joint application allows for a broader picture of SRN, in addition to the non-scientific view contributed by stakeholders participating in the transdisciplinary research process. Public debates can be encouraged by bringing together different kinds of knowledge. 
Frankfurt Social Ecology's contribution to coping with crises of societal relations to nature evolves in a twofold way: First, it aims at developing appropriate solutions to ecological crises by tackling their social, political, and economic causes. Second, it offers solutions to the epistemological and methodological challenges of sustainability science by advancing a critical, transdisciplinary mode of research.

\section{Social Ecology Vienna}

Social ecology as studied at the Institute of Social Ecology in Vienna shares with the ISOE in Frankfurt the identification of real-world problems as its point of departure. In the current social-ecological crisis, the underlying causes are systemic. The crisis is not the aggregate effect of individual, personal resource use but of the societal organization of resource use, i.e., of societal relations to nature. Social ecology in Vienna deliberately has a name that distinguishes it from human ecology. Social ecology's object of study is not humans per se-distinct from plants and other animals-but the societies within which these humans organize their reproduction [6]. From high rates of deforestation, water extraction, and fossil fuel combustion to soil degradation, and the pollution of aquifers and air, the "Great Acceleration" since the 1950s [24] has led to unprecedented patterns of global resource use. From a social-ecological perspective, this new quality and magnitude of environmental impact is associated with a comparable shift in societal organization and in the socio-economic drivers of this environmental impact.

Social ecology in Vienna conceptualizes human societies as "hybrid", as simultaneously subject to biophysical and socio-cultural spheres of causation [25] (Figure 1). Society has a "biophysical compartment", containing its human population, livestock, its infrastructure and artefacts, and must entertain biophysical relations with its natural environment in order to maintain and reproduce this compartment. This conceptualization of society is a prerequisite to the systematic study of societies across time and space in terms of their material and energetic inputs and outputs [26], i.e., of their social metabolism, and of their colonizing interventions in the environment. In this context, social metabolism is used to refer to a society's energetic and material inputs, their transformation, and either integration into societal stocks or output in the shape of exports to other socio-economic systems, or discharge to the environment as wastes and emissions [27]. Colonization describes societal interventions in the environment that aim to render that environment more societally useful than it was prior to the intervention, or than it would be if the intervention were to cease. Deforestation and tilling are examples of colonizing activities that enable the agricultural use of land for society's biomass metabolism. Social-ecological research is currently advancing to specify the decisive role that society's biophysical stocks play for resource flows [28], constituting a legacy of past decisions for future development options (Haberl et al., this issue). The material exchange with the environment is not only the result of biophysical needs but is shaped by societal perceptions of nature (and what constitutes a resource), by patterns of consumption, and by socially mediated access to resources. Social metabolism must therefore also be understood as the result of a type of communication within society's cultural sphere. This communication, in turn, is enabled and shaped by the use of material and energy. The two spheres do not exist independently of one another but are mutually dependent and influential. 


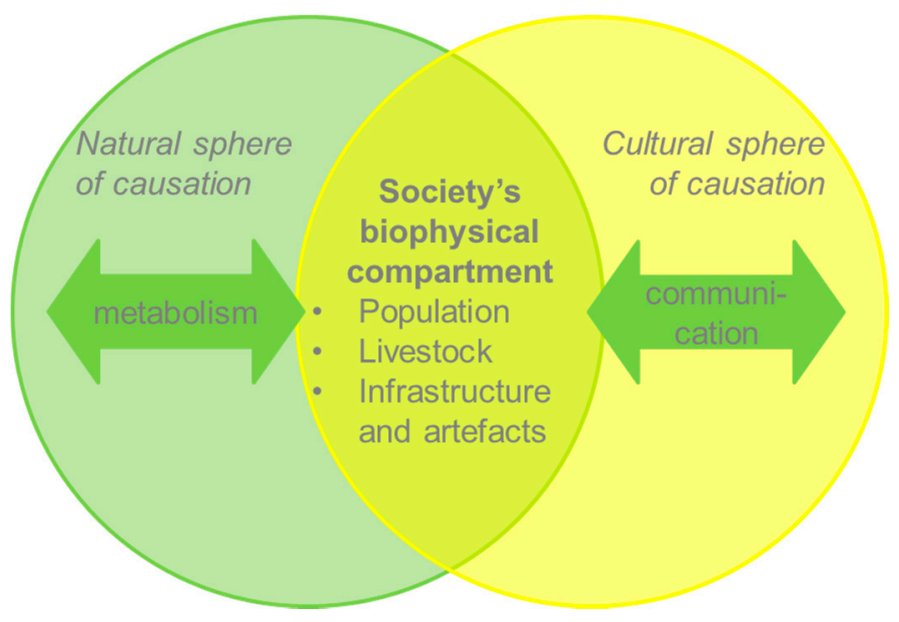

Figure 1. Schematic conceptualization of society as simultaneously shaped by a natural and a cultural sphere of causation in Vienna's social ecology.

Social-ecological research scrutinizes patterns of resource use and societal mechanisms that, intentionally or unintentionally, shape these patterns. In turn, changes to these patterns constitute a change to the societal relations to nature, including an altered form of communication about the environment and the resources it provides. To understand and-as has become especially pressing in the current social-ecological crisis-address patterns and drivers of societal resource use, both the natural and the cultural spheres of causation must be taken into account. In doing so, it becomes apparent that specific socio-cultural (political, economic, etc.) mechanisms are in place through which society organizes its metabolism. These mechanisms are simultaneously the product of and the prerequisite for specific forms of resource use [5].

Social-ecological research has uncovered important dynamics of this societal organization of metabolism through the study of past transitions between so-called socio-metabolic modes. Socio-metabolic modes are a meta-distinction between societies according to their resource basis and were introduced by the environmental historian Rolf-Peter Sieferle [29,30]. Hunters and gatherers, agrarian societies, and industrial societies have distinct socio-metabolic modes. Hunters and gatherers passively use solar energy (via biomass hunted or gathered), agrarian societies engage in a controlled solar energy use (biomass cultivated in agricultural systems), and industrial societies mainly obtain their energy via the use of fossil fuels, i.e., by harnessing the products of solar energy influx of the past. The average human requires three billion Joules (Gigajoules GJ) of energy per year in order to survive, as direct nutritional energy and with some use of firewood in order to reduce the amount of energy expended in the digestion of that biomass. Humans living together in a society of hunters and gatherers, with minimal material possessions, use almost four times that amount of energy per person (11 GJ/cap) per year. Agrarian societies use almost 17 times as much (50 GJ/cap), and industrial societies use an average of $200 \mathrm{GJ} /$ cap, i.e., more than 66 times the basic metabolic rate [31]. The particular form of societal organization, and not the sum of basic needs of its inhabitants, is decisive for societal relations to nature. Social-ecological research has demonstrated that sustainability (or lack thereof) is shaped socio-culturally and through resource use patterns (Gizicki-Neundlinger and Güldner, Haas and Andarge, Schaffartzik and Pichler, Haberl et al., all this issue), which must be understood as being interconnected.

Social ecology research in Vienna has focused strongly, but not exclusively, on the quantification of society's metabolism. This has included studies of global resource use $[32,33]$ as well as of resource use by world regions [34,35], countries [36], and local communities [37,38], (Haas and Andarge, this issue). Data availability differs strongly along these levels of scale, resulting in vast differences in the type of research conducted. Across spatial levels of scale, social ecology is also characterized by a broad range of applications to different time scales. These range from long-term socio-ecological research 
(LTSER) [39] covering millennia of societal resource use [40], (Gizicki-Neundlinger and Güldner in this issue) to studies focusing on current levels of resource use and their development in the more immediate past (Haas and Andarge, Schaffartzik and Pichler, in this issue).

While at and above the national level and for shorter, more recent periods of time, research can rely on national statistics (with some modelling of unreported flows), work at the subnational level and for a historically distant past always requires either estimation procedures or primary data collection. Especially at the community level, social-ecological research has been characterized by a much stronger (and indispensable) link between quantitative and qualitative approaches, where the quantitative data could only be gathered or verified through historical archive material (see Gizicki-Neundlinger and Güldner in this issue) or through interviews and participant observation (see Haas and Andarge in this issue). The latter practices in particular have allowed this branch of social-ecological research to contribute to questioning and reflecting on the role of the researcher [41]. There has never been any strong idea of an "objective" understanding of sustainability, even in the data-driven analyses within social ecology.

Research across levels of scale continues to provide a challenge in the field of social ecology. In rising to this challenge, much has already been discovered about links across levels of scale. Past legacies shape current resource use (Haberl et al., this issue) and drivers of resource use may originate at a spatial distance from where they take effect [42]. The fast pace and strong environmental implications of globalization for sustainability that characterize the current crisis require this type of multi-scalar approach. Future social ecology research is likely to be concerned to a greater degree with the links across different levels of scale [5].

The ability to quantify society's metabolism has developed into one of the strengths of the research conducted at the Institute of Social Ecology in Vienna and has been decisive in generating insights into the biophysical dimensions of particular patterns of economic growth, of land use or of trade relations. This research was essential in fostering the notion of strong sustainability in which natural resources are not considered to be substitutable by financial capital. Indicators derived from material flow accounting, the tool with which social metabolism is measured [43], have been implemented in national and, for example, European statistics [44], and now provide a measure of the biophysical size of an economy which is statistically independent from the leading monetary indicators (including GDP).

\section{Where to in Times of Crisis?}

The two approaches to social ecology presented in this special issue provide a productive framework for conceptualizing different dimensions, dynamics, and scales of the social-ecological crisis. At the same time, persisting and new dynamics of non-sustainable societal relations to nature constitute challenges for social-ecological research. Such challenges comprise, for instance, inequality and power asymmetries (e.g., due to climate change, or in terms of access to resources or ecosystem services), dysfunctional technological systems (e.g., due to path dependencies, inertia or lock-in situations in the energy, water or traffic sector), unjust transformations (e.g., when the introduction of innovations leads to discrimination between user groups or a disparate distribution of benefits, costs and risks), or interdependencies of different scales (e.g., local and regional actions and practices versus transregional and global impacts of pollutants such as pharmaceuticals or microplastics). In the following, we highlight some emerging clusters of challenges to which social ecology is making important contributions. These are (1) the role of power relations in enabling and maintaining unsustainable resource use patterns; (2) the role of social-ecological innovation within transformation processes; and (3) transregional interdependencies crucial for the analysis of societal relations to nature and their transformation towards sustainability.

In considering and contributing to research on power relations that shape access to, control of, and distribution of resources and environmental benefits, social ecology has developed important, fruitful links to the field of political ecology. Political ecology highlights the political and economic dimensions of crisis phenomena by asking whose crisis it is [45]. In highlighting "that unequal relations between 
actors are a key factor in understanding patterns of human-environment interaction and the associated environmental problems" [45], detailed studies analyze how powerful groups of actors control access to nature, natural resources and ecosystems through specific mechanisms (e.g., capital accumulation, commodification, gender relations, institutional settings) and how marginalized groups of actors (e.g., peasants, indigenous people, fisherfolk, urban dwellers) react to these inequalities [46-48]. The focus of social ecology on the environmental impact of a society's resource use (see Section 3) does not imply that every member of a society contributes equally to that resource use. In fact, the dominant capitalist mode of production and consumption limits the power of individuals to directly affect change so that political and economic drivers and interwoven power relations are decisive for understanding the social-ecological crisis. Focusing on these political and economic dynamics of crisis phenomena implies taking related conflicts into account [49]. Conflicts serve "as a prime form and expression of politics" [50], where underlying relations of power and domination and (contradictory) interests are revealed. Research has shown that societal elites (e.g., state representatives, companies, local elites), for example, actively produce resource scarcities through enclosure processes and the commodification of resources, which exclude other actors from their lands and resources [51,52]. Hence, social-ecological conflicts and crisis phenomena do not necessarily emerge from universal and abstract "limits to growth" or planetary boundaries $[2,53]$ but through socio-economic and political processes that shape societal relations to nature.

\subsection{Transformation through Social-Ecological Innovation}

Sustainability transformations play a crucial role in coping with social-ecological crises (see Görg et al., this issue). Since societal relations to nature are often facilitated through technological regimes (e.g., supply and disposal infrastructures, production and consumption patterns), it is important to understand the factors and processes that foster or hamper regime transitions and/or transformations which are in turn largely influenced by innovation processes. Technological regimes are a sum of institutions and infrastructures such as technologies, engineering practices, skills and procedures, and problem definitions [54]. The concept of technological regimes can describe and explain the predominance of a (dominant) technique and the rules that enable or constrain directions of development [55]. The concept can be applied to better understand innovation or to develop options for steering or managing technology. Especially if resource inefficiency is identified as the cause of environmental problems, technological innovations are often considered as a potential solution. Technology by itself, however, is not able to facilitate sustainable transformation. In the sustainable transformation of water infrastructures [56,57], for example, the invention of water-saving reuse technologies will only be achieved by "reorganizing the world around these technological inventions" [58]. A technological invention and the pursuant innovation must be accompanied by social, economic, and organizational innovations. These comprise, for instance, innovations in routine economic cycles of production and consumption, organizational structures, and acceptance by the users. In addition, the dimension of socio-technical systems necessarily needs to be complemented by an ecological dimension in order to fully grasp the societal relations to nature, i.e., the social-ecological conditions and impacts of technological innovations. The activities, perceptions, and interests of actors such as engineers, researchers, political decision-makers, users, and customers have to be integrated productively. Technological innovation can cause conflict among the involved actors. Research and practice (societal actors) must collaborate closely and negotiate the innovation process to achieve sustainable results. Research and planning become reflexive and iterative processes, which embrace openness and unanticipated contingencies (see Liehr et al. in this issue). Obstacles to innovation must be identified in advance, e.g., institutional barriers, which require other innovations, such as new institutional arrangements. In particular, measures leading to cooperative management have the potential to support the necessary restructuring of institutional arrangements and pave the way for transformation $[59,60]$. 


\subsection{Global and Transregional Interdependencies}

Global resource use regimes, transregional economic and commodity chains, and global information flows increasingly connect people, states, economies, and regions. The realms of everyday life in countries of the Global North depend on imported resources, which often stem from the Global South ([61], see Schaffartzik and Pichler in this issue). Flows and connections include, for example, exchange of resources through international trade [35,62], such as coal shipped from South America to be burned in German power plants. The social $[63,64]$ and the environmental dimension $[53,65]$ of these interconnections are objects of intensive research on the social-ecological impacts of scale interdependencies. Ecological and biophysical processes like wind systems, ocean currents, or the conditions of resources like soil and water, are impacted by and have impacts on these international resource flows. For example, microplastics and other chemicals are distributed around the world, posing a global risk [22], and invasive species carried by ships or long-distance traffic on land upset local ecosystemic balances [66]. In order to study such interdependencies, social and ecological analyses, including spatial and temporal dimensions, must be combined, considering natural processes (such as ocean currents, wind), technical processes (technologies), and social processes (communication, practices, trade, politics). The debate on the Anthropocene has triggered questions of scale regarding the tension between the diagnosis of a global social-ecological crisis with responsibility and potential for action on a local and regional scale [67]. Social ecology has begun to integrate concepts which have been used to fruitfully study multi-scalar interdependencies and which include social-ecological systems [68,69], tele-coupling [70-72], virtual water [73], and the flat ontology approach developed by ANT researchers [74].

\section{Future Prospects for Social-Ecological Research}

Each of the approaches to social ecology presented in this special issue contribute to our understanding of the crisis of the societal relations to nature. Each approach has also developed its specific foci. Frankfurt Social Ecology has developed social ecology as a critical, transdisciplinary science which addresses real-world problems in order to shape societal relations to nature in a sustainable way. The work at the Institute of Social Ecology in Vienna has been instrumental in the consideration of society as biophysical and as therefore subject to the impact of a changed environment. Both approaches to social ecology share an understanding of the problems and challenges posed by social-ecological crises and the need to develop responses, solutions, and coping strategies that must include shaping the scientific and public discourse on societal relations to nature. Social-ecological research has identified that and how the sustainability of societal resource use patterns (or more appropriately: the lack of sustainability therein) is systemic and-partially-unintended. These research insights raise serious concern as to the ability of many of the mainstream political and policy measures to adequately address the current crisis. Achieving sustainability is not a question of a few 'tweaks' to the system, it is a question of transformations of our very fundamental societal relations to nature. Social-ecological research can generate knowledge and instate academic practices that greatly contribute to such transformations by rising to the challenge of the current crisis. This is undoubtedly a tall order, and the research in social ecology is far from completed. Nor will or should the research on sustainability transformations be understood as the domain of social ecology alone: New cooperation across disciplinary boundaries and in the public domain must play a catalytic role in the future of this research field. At the same time, the intensified exchange among social ecologists, in which this special issue constitutes but a small step forward, provides a positive challenge for the further development of the field.

Acknowledgments: The authors wish to thank Thomas Jahn and Florian Keil for their helpful suggestions and comments.

Author Contributions: J.K., M.P., A.S., and M.Z. developed the concept and wrote the article. Section 2 was written mainly by J.K. and M.Z. Section 3 was written mainly by A.S. and M.P. 
Conflicts of Interest: The authors declare no conflict of interest.

\section{References}

1. Becker, E. Soziale Ökologie-Konstitution und Kontext. In Soziale Ökologie. Grundzüge einer Wissenschaft von den Gesellschaftlichen Naturverhältnissen; Becker, E., Jahn, T., Eds.; Campus Verlag: Frankfurt, Germany; New York, NY, USA, 2006; pp. 29-53.

2. Meadows, D.H.; Meadows, D.H.; Randers, J.; Behrens, W.W., III. The Limits to Growth: A Report to the Club of Rome (1972); Universe Books: New York, NY, USA, 1972.

3. World Commission on Environment and Development. Our Common Future. In Report of the World Commission on Environment and Development; United Nations: New York, NY, USA, 1987.

4. Crutzen, P.J. Geology of mankind. Nature 2002, 415, 23. [CrossRef] [PubMed]

5. Pichler, M.; Schaffartzik, A.; Haberl, H.; Görg, C. Drivers of society-nature relations in the Anthropocene and their implications for sustainability transformations. Curr. Opin. Environ. Sustain. 2017, 26-27, 32-36. [CrossRef]

6. Fischer-Kowalski, M.; Weisz, H. The archipelago of social ecology and the island of the Vienna school. In Social Ecology. Society-Nature Relations across Time and Space; Haberl, H., Fischer-Kowalski, M., Krausmann, F., Winiwarter, V., Eds.; Springer International Publishing: Cham, Germany, 2016; Volume 5, pp. 3-28.

7. Fischer-Kowalski, M.; Weisz, H. Society as Hybrid between Material and Symbolic Realms. Towards a Theoretical Framework of Society-nature Interaction. Adv. Hum. Ecol. 1999, 8, 215-251.

8. Beck, U. Risk Society: Towards a New Modernity; Theory, culture \& society; Sage Publications: London, UK; Newbury Park, CA, USA, 1992.

9. Latour, B. Reassembling the Social: An Introduction to Actor-Network-Theory; Clarendon lectures in management studies; Oxford Univ. Press: Oxford, UK, 2007.

10. Voss, M.; Peuker, B. (Eds.) Verschwindet Die Natur? Die Akteur-Netzwerk-Theorie in der Umweltsoziologischen Diskussion; Transcript: Bielefeld, Germany, 2006.

11. Jahn, T. Transdisziplinarität in der Forschungspraxis. In Transdisziplinäre Forschung. Integrative Forschungsprozesse Verstehen und Bewerten; Bergmann, M., Schramm, E., Eds.; Campus Verlag: Frankfurt, Germany; New York, NY, USA, 2008; pp. 21-37.

12. Mittelstrass, J. Methodische Transdisziplinarität. Tech. Theor. Prax. 2005, 14, 18-23.

13. Jahn, T.; Bergmann, M.; Keil, F. Transdisciplinarity: Between mainstreaming and marginalization. Ecol. Econ. 2012, 79, 1-10. [CrossRef]

14. Winker, M.; Schramm, E.; Schulz, O.; Zimmermann, M.; Liehr, S. Integrated water research and how it can help address the challenges faced by Germany's water sector. Environ. Earth Sci. 2016, 75, 1226. [CrossRef]

15. Deffner, J. Sustainable mobility cultures and the role of cycling planning professionals. ISOE Policy Brief. 2015, 3, 1-5.

16. Stieß, I.; Dunkelberg, E. Objectives, barriers and occasions for energy efficient refurbishment by private homeowners. J. Clean. Prod. 2013, 48, 250-259. [CrossRef]

17. Stieß, I.; Rubik, F. Alltagsroutinen klimafreundlicher gestalten. Ökol. Wirtsch. 2015, 30, 39-45. [CrossRef]

18. Hummel, D.; Lux, A. Population decline and infrastructure. The case of the German water supply system. Vienna Yearb. Popul. Res. 2007, 5, 167-191. [CrossRef]

19. Mehring, M. How to frame social-ecological biodiversity research. A methodological comparison between two approaches of social-ecological systems. In Biodiversität und Gesellschaft. Gesellschaftliche Dimensionen von Schutz und Nutzung Biologischer Vielfalt; Friedrich, J., Halsband, A., Minkmar, L., Eds.; Universitätsverlag: Göttingen, Germany, 2013; pp. 91-98.

20. Jahn, T.; Keil, F. An actor-specific guideline for quality assurance in transdisciplinary research. Futures 2015, 65, 195-208. [CrossRef]

21. Lütkemeier, R.; Liehr, S. Drought: Research and Science-Policy Interfacing; Andreu, J., Solera, A., Paredes-Arquiola, J., Haro-Monteagudo, D., van Lanen, H., Eds.; CRC Press: London, UK, 2015; pp. 41-48.

22. Kramm, J.; Völker, C. Understanding risks of microplastics. A social-ecological risk perspective. In Freshwater Microplastics. Emerging Contaminants? Handbook of Environmental Chemistry; Wagner, M., Lambert, S., Eds.; Springer: Berlin, Germany, 2017, in press. 
23. Götz, K.; Ohnmacht, T. Research on Mobility and Lifestyle-What are the Results? In Mobilities: New Perspectives on Transport and Society; Grieco, M., Urry, J., Eds.; Ashgate Publishing, Ltd.: Farnham, UK, 2011; pp. 91-108.

24. Steffen, W.; Broadgate, W.; Deutsch, L.; Gaffney, O.; Ludwig, C. The trajectory of the Anthropocene: The Great Acceleration. Anthr. Rev. 2015, 2, 81-98. [CrossRef]

25. Fischer-Kowalski, M.; Weisz, H. Society as hybrid between material and symbolic realms: Toward a theoretical framework of society-nature interaction. Adv. Hum. Ecol. 1999, 8, 215-252.

26. Ayres, R.U.; Kneese, A.V. Production, consumption, and externalities. Am. Econ. Rev. 1969, 59, $282-297$.

27. Fischer-Kowalski, M.; Haberl, H. Social metabolism: A metric for biophysical growth and degrowth. In Handbook of Ecological Economics; Martinez-Alier, J., Ed.; Edward Elgar Publishing: Cheltenham, UK, 2015; pp. 100-138.

28. Krausmann, F.; Wiedenhofer, D.; Lauk, C.; Haas, W.; Tanikawa, H.; Fishman, T.; Miatto, A. Global socioeconomic material stocks rise 23-fold over the 20th century and require half of annual resource use. Proc. Natl. Acad. Sci. USA 2017, 114, 1880-1885. [CrossRef] [PubMed]

29. Sieferle, R.P. Sustainability in a world history perspective. In Exploitation and Overexploitation in Societies Past and Present; Benzig, B., Ed.; LIT Publishing House: Münster, Germany, 2003; pp. 123-142.

30. Sieferle, R.P. Rückblick auf Die Natur. Eine Geschichte des Menschen und Seiner Umwelt; Luchterhand: Munich, Germany, 1997.

31. Fischer-Kowalski, M.; Schaffartzik, A. Energy availability and energy sources as determinants of societal development in a long-term perspective. MRS Energy Sustain. A Rev. J. 2015, 2. [CrossRef]

32. Krausmann, F.; Erb, K.-H.; Gingrich, S.; Haberl, H.; Bondeau, A.; Gaube, V.; Lauk, C.; Plutzar, C.; Searchinger, T.D. Global human appropriation of net primary production doubled in the 20th century. Proc. Natl. Acad. Sci. USA 2013, 110, 10324-10329. [CrossRef] [PubMed]

33. Krausmann, F.; Gingrich, S.; Eisenmenger, N.; Erb, K.-H.; Haberl, H.; Fischer-Kowalski, M. Growth in global materials use, GDP and population during the 20th century. Ecol. Econ. 2009, 68, 2696-2705. [CrossRef]

34. Erb, K.-H.; Krausmann, F.; Lucht, W.; Haberl, H. Embodied HANPP: Mapping the spatial disconnect between global biomass production and consumption. Ecol. Econ. 2009, 69, 328-334. [CrossRef]

35. Schaffartzik, A.; Mayer, A.; Gingrich, S.; Eisenmenger, N.; Loy, C.; Krausmann, F. The global metabolic transition: Regional patterns and trends of global material flows, 1950-2010. Glob. Environ. Chang. 2014, 26, 87-97. [CrossRef] [PubMed]

36. Niedertscheider, M.; Kuemmerle, T.; Müller, D.; Erb, K.H. Exploring the effects of drastic institutional and socio-economic changes on land system dynamics in Germany between 1883 and 2007. Glob. Environ. Chang. 2014, 28, 98-108. [CrossRef] [PubMed]

37. Ringhofer, L. Time, Labour and the Household: Measuring “Time Poverty" through a Gender Lens. Dev. Pract. 2015, 25, 321-332. [CrossRef]

38. Singh, S.J.; Grünbühel, C.M.; Schandl, H.; Schulz, N. Social Metabolism and Labour in a Local Context: Changing Environmental Relations on Trinket Island. Popul. Environ. 2001, 23, 71-104. [CrossRef]

39. Haberl, H.; Winiwarter, V.; Andersson, K.; Ayres, R.U.; Boone, C.G.; Castillo, A.; Cunfer, G.; Fischer-Kowalski, M.; Freudenburg, W.R.; Furman, E.; et al. From LTER to LTSER: Conceptualizing the Socioeconomic Dimension of Long-term Socioecological Research. Ecol. Soc. 2006, 11, 13. [CrossRef]

40. Gingrich, S.; Kuskova, P.; Steinberger, J.K. Long-term changes in $\mathrm{CO}_{2}$-emissions in Austria and Czechoslovakia-Identifying the drivers of environmental pressures. Energy Policy 2011, 39, 535-543. [CrossRef] [PubMed]

41. Singh, S.J.; Haas, W. Complex Disasters on the Nicobar Islands. In Social Ecology. Society-Nature Relations across Time and Space; Haberl, H., Fischer-Kowalski, M., Krausmann, F., Winiwarter, V., Eds.; Springer International Publishing: Cham, Germany, 2016; Volume 5, pp. 523-538.

42. Schaffartzik, A.; Brad, A.; Pichler, M.; Plank, C. At a Distance from the territory: Distal drivers in the (Re)territorialization of oil palm plantations in Indonesia. In Land Use Competition. Ecological, Economic and Social Perspectives; Niewöhner, J., Bruns, A., Hostert, P., Krüger, T., Nielsen, J.Ø., Haberl, H., Lauk, C., Lutz, J., Müller, D., Eds.; Springer International Publishing: Cham, Germany, 2016.

43. Fischer-Kowalski, M.; Krausmann, F.; Giljum, S.; Lutter, S.; Mayer, A.; Bringezu, S.; Moriguchi, Y.; Schütz, H.; Schandl, H.; Weisz, H. Methodology and Indicators of Economy-wide Material Flow Accounting. J. Ind. Ecol. 2011, 15, 855-876. [CrossRef] 
44. Eurostat Economy-wide Material Flow Accounts (EW-MFA). Compilation Guide; Eurostat: Luxembourg, 2013.

45. Bryant, R.L.; Bailey, S. Third World Political Ecology; Routledge: London, UK; New York, NY, USA, 1997.

46. Pichler, M. Legal Dispossession: State Strategies and Selectivities in the Expansion of Indonesian Palm Oil and Agrofuel Production. Dev. Chang. 2015, 64, 508-533. [CrossRef]

47. Schäfer, M.; Schultz, I.; Wendorf, G. (Eds.) Gender-Perspektiven in der Sozial-ökologischen Forschung. Herausforderungen und Erfahrungen aus Inter- und Transdisziplinären Projekten; Oekom Verlag: München, Germany, 2006.

48. Dietz, K.; Engels, B.; Pye, O.; Brunnengräber, A. (Eds.) The Political Ecology of Agrofuels; Routledge ISS studies in rural livelihoods; Routledge: Abingdon, Oxon, UK; New York, NY, USA, 2015.

49. Pichler, M.; Brad, A. Political Ecology and Socio-Ecological Conflicts in Southeast Asia. Austrian J. South-East Asian Stud. 2016, 9, 1-10.

50. Le Billon, P. Environmental conflict. In The Routledge Handbook of Political Ecology; Perreault, T., Bridge, G., McCarthy, J., Eds.; Routledge: New York, NY, USA, 2015; pp. 598-608.

51. Brad, A.; Schaffartzik, A.; Pichler, M.; Plank, C. Contested territorialization and biophysical expansion of oil palm plantations in Indonesia. Geoforum 2015, 64, 100-111. [CrossRef]

52. Ley, L. "Dry Feet for All": Flood Management and Chronic Time in Semarang, Indonesia. Austrian J. South-East Asian Stud. 2016, 9, 107.

53. Rockström, J.; Steffen, W.; Noone, K.; Persson, Å.; Chapin, F.S.; Lambin, E.F.; Lenton, T.M.; Scheffer, M.; Folke, C.; Schellnhuber, H.J.; et al. A safe operating space for humanity. Nature 2009, 461, 472-475. [CrossRef] [PubMed]

54. Rip, A.; Kemp, R. Technological Change. In Human Choice and Climate Change; Rayner, S., Malone, E.L., Eds.; Battelle Press: Columbus, OH, USA, 1998; pp. 327-399.

55. Van de Poel, I.R.; Franssen, M.P.M. Understanding technical development. The concept of "Technological Regime". IJTPM 2002, 2, 355. [CrossRef]

56. Kluge, T.; Libbe, J. (Eds.) Transformationsmanagement für eine Nachhaltige Wasserwirtschaft. Handreichung zur Realisierung Neuartiger Infrastrukturlösungen im Bereich Wasser und Abwasser; [Ergebnisse des Forschungsverbunds netWORKS]; SÖF-Sozial-Ökologische Forschung; Difu: Berlin, Germany, 2010.

57. Kluge, T.; Schramm, E. Wasser 2050. Mehr Nachhaltigkeit Durch Systemlösungen; oekom: München, Germany, 2016.

58. Kaghan, W.; Bowker, G. Out of machine age? Complexity, sociotechnical systems and actor network theory. J. Eng. Technol. Manag. 2001, 18, 253-269. [CrossRef]

59. Kerber, H.; Schramm, E.; Winker, M. Transformationsrisiken Bearbeiten: Umsetzung Differenzierter Wasserinfrastruktursysteme Durch Kooperation; Forschungsverbund netWORKS, Ed.; netWORKS-Papers; Deutsches Institut für Urbanistik Difu: Berlin, Germany, 2016; Volume 28.

60. Schramm, E.; Kerber, H.; Trapp, J.H.; Zimmermann, M.; Winker, M. Novel urban water systems in Germany: Governance structures to encourage transformation. Urban Water J. 2017, in press. [CrossRef]

61. Brand, U.; Wissen, M. Crisis and continuity of capitalist society-nature relationships: The imperial mode of living and the limits to environmental governance. Rev. Int. Polit. Econ. 2013, 20, 687-711. [CrossRef]

62. Giljum, S.; Eisenmenger, N. North-South Trade and the Distribution of Environmental Goods and Burdens: A Biophysical Perspective. J. Environ. Dev. 2004, 13, 73-100. [CrossRef]

63. Appadurai, A. Modernity at Large. Cultural Dimensions of Globalization; University of Minnesota Press: Minneapolis, MN, USA, 1996.

64. Castells, M. The rise of the network society. In The Information Age: Economy, Society, and Culture; Wiley-Blackwell: Oxford, UK, 2011.

65. Schellnhuber, H.J.; Crutzen, P.J.; Clark, W.C.; Hunt, J. Earth System Analysis for Sustainability. Environ. Sci. Policy Sustain. Dev. 2005, 47, 10-25. [CrossRef]

66. Hulme, P.E. Trade, transport and trouble: Managing invasive species pathways in an era of globalization. J. Appl. Ecol. 2009, 46, 10-18. [CrossRef]

67. Jahn, T.; Hummel, D.; Schramm, E. Sustainable science in the anthropocene. In ISOE Discussion Paper; ISOE_-Institute for Social-Ecological Research: Frankfurt am Main, Germany, 2016.

68. Becker, E. Social-Ecological systems as epistemic objects. In Human Nature Interactions in the Anthropocene: Potentials of Social-Ecological Systems Analysis; Glaser, M., Krause, G., Ratter, B., Welp, M., Eds.; Routledge: London, UK, 2012; pp. 37-59. 
69. Berkes, F.; Colding, J.; Folke, C. Navigating Social-Ecological Systems: Building Resilience for Complexity and Change; Cambridge University Press: Cambridge, UK, 2008.

70. Bruckner, M.; Fischer, G.; Tramberend, S.; Giljum, S. Measuring telecouplings in the global land system. A review and comparative evaluation of land footprint accounting methods. Ecol. Econ. 2015, 114, 11-21. [CrossRef]

71. Haberl, H.; Erb, K.-H.; Krausmann, F.; Berecz, S.; Ludwiczek, N.; Martinez-Alier, J.; Musel, A.; Schaffartzik, A. Using embodied HANPP to analyze teleconnections in the global land system: Conceptual considerations. Geogr. Tidsskr. Dan. J. Geogr. 2009, 109, 119-130. [CrossRef]

72. Friis, C.; Østergaard Nielsen, J.; Otero, I.; Haberl, H.; Niewöhner, J.; Hostert, P. From teleconnection to telecoupling: Taking stock of an emerging framework in land system science. J. Land Use Sci. 2016, 11, 131-153. [CrossRef]

73. Chapagain, A.K.; Hoekstra, A.Y. The global component of freshwater demand and supply: An assessment of virtual water flows between nations as a result of trade in agricultural and industrial products. Water Int. 2008, 33, 19-32. [CrossRef]

74. Latour, B. On actor-network theory: A few clarifications. Soz. Welt 1996, 47, 369-381.

(C) 2017 by the authors. Licensee MDPI, Basel, Switzerland. This article is an open access article distributed under the terms and conditions of the Creative Commons Attribution (CC BY) license (http:/ / creativecommons.org/licenses/by/4.0/). 